\title{
DETECTION OF Vibrio parahaemolyticus AND Vibrio cholerae IN OYSTER, Crassostrea rhizophorae, COLLECTED FROM A NATURAL NURSERY IN THE COCÓ RIVER ESTUARY, FORTALEZA, CEARÁ, BRAZIL
}

Oscarina Viana de SOUSA(1), Regine Helena Silva dos Fernandes VIEIRA(2), Francisca Gleire Rodrigues de MENEZES(3), Christiane Moura Falavina dos REIS(4) \& Ernesto HOFER( 4)

\begin{abstract}
SUMMARY
Oysters are edible organisms that are often ingested partially cooked or even raw, presenting therefore a very high risk to the consumers' health, especially in tropical regions. The presence of Vibrio cholerae and Vibrio parahaemolyticus in oysters sampled at an estuary in the Brazilian northeastern region was studied, with 300 oysters tested through an 8-months period. The salinity of the water at the sampling point varied between $3 \%$ and $27 \%$ o. V. cholerae was the most frequently detected species $(33.3 \%$ of the samples), and of the $22 \mathrm{~V}$. cholerae isolates, 20 were identified as non-O1/non-O139, with two of the colonies presenting a rough surface and most of remaining ones belonging to the Heiberg II fermentation group. V. parahaemolyticus was isolated from just one of the samples. Other bacteria such as Providencia spp., Klebsiella spp. and Morganella morganii were also isolated.
\end{abstract}

KEYWORDS: Public health; Vibrio parahaemolyticus; Vibrio cholerae; Oyster; Northeastern Brazil.

\section{INTRODUCTION}

Due to their peculiar feeding procedure - filtering the surrounding water, retaining and accumulating microorganisms and other substances - bivalves are commonly associated with the transmission of diarrhearelated microbiological agents ${ }^{22}$.

Enteropathogenic bacteria may be present in the tissues of bivalves in concentrations higher than in the source water, and since oysters are usually eaten raw they are highly correlated with gastrointestinal disorders ${ }^{8}$.

The concentration of vibrios depends on geographical and hydrographical conditions. In filtering organisms the determining factors are species, location in the water column, and time of permanence in the water ${ }^{17}$. Vibrios are part of the natural microbiota of marine and estuarine environments and some may cause infections in humans which were exposed to seafood or sea water. However, organisms commonly employed to indicate contamination give no hint of the presence of these autochthonous bacteria. Vibrio parahaemolyticus and Vibrio cholerae are pathogenic to humans. They are found in the marine and estuarine environments and may cause gastrointestinal illnesses, either in isolated cases or in the form of outbreaks ${ }^{19,24}$.

The increasing consumption of mollusks in natura, especially oysters, collected from natural nurseries and neither subjected to decontamination procedures nor adequately packed, is a matter of great concern to public health authorities, mainly in tropical countries.

The objective of this study was to investigate $V$. parahaemolyticus and $V$. cholerae colonizing oysters collected from the estuary of Rio Cocó, a river in Northeastern Brazil, in view of the popularity of these mollusks as a source of raw food.

\section{MATERIAL AND METHODS}

Sampling: Twelve batches of the oyster species Crassostrea rhizophorae were collected from the Cocó river estuary (Fortaleza, Brazil) at fortnightly intervals between October 2000 and April 2001. The batches consisted of 20-25 pooled specimens each and were transported to the laboratory in isothermal boxes within 2-3 hours after collection. All dirt was removed from the valves by thorough washing and brushing in running water prior to aseptic opening.

Enrichment and isolation: Initially a 1:9 dilution was prepared with $25 \mathrm{~g}$ of meat and liquid (depending on size, 20-25 oysters of the same batch) in $225 \mathrm{~mL}$ alkaline peptone water (APW) at $\mathrm{pH} 8.6$ with the addition of $3 \%$ sodium chloride. The homogenized sample was incubated at $42{ }^{\circ} \mathrm{C}$ for $18 \mathrm{~h}$ for enrichment and growth. Ten fold dilutions (from $10^{-2}$ to $10^{-5}$ ) in APW were inoculated onto Petri dishes containing thiosulfate-citrate-bile-saccharose agar (TCBS, Difco). After incubation at $35^{\circ} \mathrm{C}$ for $18 \mathrm{~h}$, saccharose-positive and negative colonies (three on

(1) Instituto de Microbiologia Prof. Paulo de Góes, UFRJ, RJ, Brazil.

(2) Departamento de Engenharia de Pesca and Instituto de Ciências do Mar - LABOMAR, UFC, CE, Brazil.

(3) Instituto de Ciências do Mar - LABOMAR, UFC, CE, Brazil

(4) Departamento de Bacteriologia, Instituto Oswaldo Cruz, Fiocruz, Rio de Janeiro, RJ, Brazil.

Correspondence to: Dr. Regine Helena S. dos F. Vieira, Av. da Abolição 3207, Meireles, 60165-081 Fortaleza, Ceará, Brasil. e-mail: regine@ labomar.ufc.br 


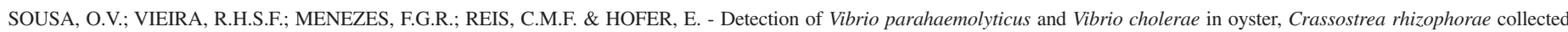
from a natural nursery in the Cocó river estuary, Fortaleza, Ceará, Brazil. Rev. Inst. Med. trop. S. Paulo, 46(2):59-62, 2004.

average) suspected of belonging to the Vibrio genus were transferred and inoculated into tubes containing triptone soy agar (TSA, Difco) with further incubation at $35^{\circ} \mathrm{C}$ for $24 \mathrm{~h}$.

Identification: Preliminarily, all cultures were submitted to an oxidase test. Strains testing oxidase-positive were identified phenotypically according to the procedures presented in the Laboratory Diagnosis Handbook ${ }^{6}$, including classification into the Heiberg groups for $V$. cholerae and the Kanagawa test for $V$. parahaemolyticus.

Results and discussion: Four out of a total of twelve samplings (with repeats), resulting from four different pools, tested positive for the presence of $V$. cholerae while one was positive for $V$. parahaemolyticus (Table 1).

Table 1

Presence of V. cholerae and V. parahaemolyticus in twelve oyster samples (Crassostrea rhizophorae) and the registered salinities at the natural nursery in the estuary of Rio Cocó (Fortaleza, Brazil)

\begin{tabular}{cccc}
\hline Samplings & V. cholerae & V. parahaemolyticus & Salinity (\%o) \\
\hline 1 & - & - & 27 \\
2 & - & - & 27 \\
3 & - & - & 27 \\
4 & - & - & 27 \\
5 & - & - & 27 \\
6 & - & - & 10 \\
7 & - & - & 8 \\
8 & - & - & 8 \\
9 & + & - & 17 \\
10 & + & - & 3 \\
11 & + & - & 3 \\
12 & + & + & 3 \\
\hline
\end{tabular}

Out of the 57 saccharose-positive strains isolated from plates with TCBS agar, 22 (39\%) were confirmed as non-O1, non-O139 V. cholerae; two strains with wrinkled surfaces were classified as V. cholerae.

$\mathrm{XU}$ et al. ${ }^{25}$ reported greater resistance in estuarine environments for $V$. cholerae than for $E$. coli, an important observation for public health authorities in charge of monitoring areas in which oysters are farmed and collected. The presence of longer-lived vibrios may compromise water quality evaluations based on coliform bacilli standards alone.

The occurrence of strains of $V$. cholerae coincided with the beginning of the local rainy season and with reduced levels of salinity in the source water (Table 1). Other authors have described the relation between salinity and isolation of $V$. cholerae in oysters. In fact, COLWELL \& HUQ ${ }^{7}$ observed a higher frequency of $V$. cholerae in areas with salinities in the range $0.2-2.0 \%$.

$V$. cholerae is found in aquatic environments either as a freeswimming organism or in association with zooplankton. Strains of nonO1, non-0139 V. cholerae are often isolated from seafood or the marine environment, but - though they may be invasive and transmitted to man by way of raw seafood - are not considered as important as serotypes $\mathrm{O} 1$ and $\mathrm{O} 139$. The medical literature registers cases of non-O1, non-
O139 V. cholerae as the causal agent of bacteremia and septicemia in patients with chronic degenerative disorders, along with a considerable number of references to gastroenteric disease ${ }^{20}$.

According to ALBERT et al. ${ }^{1}$, cholera outbreaks have been increasingly associated with the consumption of contaminated food products. Among cholera-associated seafoods, bivalves and crustaceans are the most commonly implicated.

Of the 22 strains identified as $V$. cholerae, two strains pertaining to batch \#10 had wrinkled surfaces. One of these was classified as belonging to the Heiberg I group. Of the remaining 20 strains classified as non-O1 Vibrio cholerae, five (four pertaining to batch \#10 and one to batch \#9) were found to belong to the Heiberg I group, while fourteen other strains (nine pertaining to batch \#11 and five to batch \#12) were Heiberg II and one (from batch \#12) was Heiberg IV. Our findings match those reported by HOFER \& ERNANDEZ ${ }^{15}$ working on strains of $V$. cholerae isolated from the outlet of sewage treatment plants in Rio de Janeiro. In their paper, Vibrio strains of type II were observed to prevail during the lowtemperature season, a finding confirmed by the present study. As in HOFER \& ERNANDEZ, our second-last sampling, performed during the month of April, displayed the highest number of non-O1 V. cholerae strains of Heiberg type II.

In accordance with the Bacteriological Analytical Manual ${ }^{11}$, the detection of $V$. parahaemolyticus and $V$. cholerae in oysters requires a dilution in APW to reduce competition with other vibrios. As filtering organisms, oysters ingest water and plankton which may contain different vibrios or other potential competitors of the target bacteria. On the other hand, DePAOLA \& HWANG ${ }^{9}$ associated the reduction of $\mathrm{pH}$ in the APW enrichment broth with failure to detect $V$. cholerae. Oyster meat contains plenty of glycogen, a substance producing lactic acid during fermentation and thereby reducing the $\mathrm{pH}$ during enrichment of the homogenized oyster samples ${ }^{3}$. RODRIGUES \& HOFER ${ }^{23}$ found the TCBS agar plating procedure after culture in APW at $\mathrm{pH} 8.6$ and 3\% $\mathrm{NaCl}$ to be an efficient means of detecting the majority of Vibrio spp., especially in oyster samples. They studied the presence of Vibrio in oysters and water from Baía de Sepetiba (Rio de Janeiro) and isolated 576 cultures belonging to this genus. Out of an assemblage of 390 cultures seven species were identified: $65 \%$ were non-O1 V. cholerae and $14 \%$ were $\mathrm{V}$. alginolyticus, while V. parahaemolyticus accounted for $11 \%, V$. fluvialis for $6.7 \%, V$. harveyi for $1.5 \%$ and $V$. vulnificus for $0.5 \%$.

Plating onto a selective medium such as TCBS should be followed by a simple and reliable detection procedure for the isolation of suspected Vibrio colonies. Such conditions may be attained in samples of cooked food, but in highly contaminated foods in natura such as oysters vibrios will often be underestimated because of the large number of competing microorganisms. The most common competitors of $V$. parahaemolyticus and $V$. cholerae are non-fermenting gram-negative bacteria, other Vibrio subspecies, enterobacteriaceae and, to a lesser degree, Enterococcus, Staphylococcus and Micrococcus $\operatorname{spp}^{10}$.

In our study $V$. parahaemolyticus was detected in a single sampling and, as expected, was Kanagawa-negative.

The salinity of the water in the estuary ranged from 3 to $27 \%$ (Table 1). Such oscillation may in part account for the reduced number of isolated 
strains. Thus, one would expect to detect a larger number of Vibrio parahaemolyticus strains in water with a salinity between 2 and $4 \%$, considered to be ideal for the species ${ }^{18}$.

In a study involving seafood, HARA-KUDO et al. ${ }^{13}$ observed that colonies of $V$. parahaemolyticus in TCBS medium are difficult to distinguish from other colonies. The acids produced by saccharosefermenting bacteria become diffused over the agar, changing the color of the medium from green to yellow in the vicinity of the colonies. The $V$. parahaemolyticus colonies near these bacteria may therefore become camouflaged making isolation a difficult task. The use of solid media containing substrates for the enzyme beta-galactosidase has been proposed as a means of minimizing this problem. In the case of mollusks, one must also take into account the organisms' own defense mechanisms such as the presence in the serum of phagocytes capable of eliminating vibrios as well as the presence of antibacterial and antiviral substances in the homogenized oyster samples ${ }^{5,12,14,16}$.

Through its Resolution 12/01, the Department of Sanitary Vigilance has determined the maximum acceptable level of Vibrio parahaemolyticus in raw seafood-based dishes to be $10^{3}$ per gram ${ }^{4}$. Though oysters are not mentioned explicitly in this paragraph, they may be considered a raw seafood since they are traditionally consumed in natura.

The fact that some of the isolated strains presented sour gas, making the isolation of Vibrio more difficult, suggests an association between the gas-producing bacteria and bacteria of this genus. This inference was further supported by the identification, among the strains isolated from the TCBS plates, of Proteus spp. and Morganella morganii, which are known to produce the gas $\mathrm{H}_{2} \mathrm{~S}^{21}$. The bacteria belonging to these genera are found naturally in the environment and colonize the intestines of animals and healthy humans ${ }^{2}$.

Furthermore, Providencia spp., Klebsiella spp., Proteus spp. and Morganella morganii were identified in $41 \%, 8.3 \%, 16.6 \%$, and $8.3 \%$ of the oyster samples, respectively.

The presence of non-O1 Vibrio cholerae in the oysters analyzed in this study is disquieting, considering that the animals were collected in Fortaleza's largest mangrove swamp and that oysters from this area are marketed and consumed raw by the local population. With an appropriate thermal treatment such food represents a significant risk for enteric disease.

\section{RESUMO}

\section{Isolamento de Vibrio parahaemolyticus e Vibrio cholerae em ostras, Crassostrea rhizophorae, coletadas em um criadouro natural no estuário do rio Cocó, Fortaleza, Ceará, Brasil}

As ostras são alimentos marinhos freqüentemente ingeridos crus ou parcialmente cozidos. Por esta razão, o risco para a saúde dos consumidores desses produtos é muito elevado, principalmente, quando são de regiões tropicais. Foi estudada a presença de Vibrio cholerae e Vibrio parahaemolyticus em ostras de um estuário na região Nordeste do Brasil. Trezentas ostras foram analisadas, em um período de 8 meses. A salinidade da água, no local de coleta, variou de 3 a $27 \%$. V. cholerae foi o vibrio mais freqüentemente detectado (33,3\% das amostras). Dos 22 isolados, 20 foram identificados como V. cholerae não-O1/não-O139, duas delas apresentando forma rugosa sendo a maioria das demais pertencente ao tipo fermentativo Heiberg II. V. parahaemolyticus foi isolado em apenas umas das coletas. Foram, também, identificadas nas amostras isolados de Providencia spp., Klebsiella spp., Proteus spp. e Morganella morganii.

\section{REFERENCES}

1. ALBERT, M.J.; NEIRA, M. \& MOTARJEMI, Y. - The role of food in the epidemiology of cholera. Wld. Hlth. Statist. Quart., 50: 111-118, 1997.

2. ALEKSIC, S. \& BOCKEMUHL, J. - Yersinia and other Enterobacteriaceae. In: MURRAY, P.R.; BARON, E.J; PFALLER, M.A.; TENOVER, F.C. \& YOLKEN, R.H., ed. Manual of clinical microbiology. Washington, American Society for Microbiology, 1999. p. 483-496.

3. ALEXANDER, D.; DePAOLA, A.; CHIRTEL, S. \& YOUNG, R.B. - Detection of Vibrio cholerae in oyster (Crassostrea virginica) homogenate based on centrifugal removal of antimicrobial agents. J. microbiol. Meth., 33: 237-244, 1998.

4. ANVISA. Agência Nacional de Vigilância Sanitária - Resolução- RDC $n^{0} 12$, de 02 de janeiro de 2001. Regulamento técnico sobre os padrões microbiológicos para alimentos. Diario Oficial da República Federativa do Brasil, Brasília, DF, 10 de janeiro de 2001

5. BACHERE, E.; HERVIO, D.; MIALHE, E. \& GRIZEL, H. - Evidence of neutralizing activity against T3-coliphage in oyster Crassostrea-gigas hemolymph. Dev. comp. Immunol., 14: 261-268, 1990.

6. BRASIL. Ministério da Saúde - Manual de diagnóstico laboratorial. Cólera. Brasília, Cnpc- Subcomissão Nacional de Diagnóstico Laboratorial, 1992.

7. COLWELL, R.R. \& HUQ, A. - Vibrios in the environmental: viable but nonculturable Vibrio cholerae. In: WACHSMUTH, I.K.; BLAKE, P.A. \& OLSVIK, O., ed. Vibrio cholerae and cholera: molecular to global perspectives. Washington, American Society for Microbiology, 1994. p. 127-133.

8. DANIELS, N.A.; MACKINNON, L.; BISHOP, R. et al. -Vibrio parahaemolyticus infections in the United States, 1973-1998. J. infect. Dis., 181: 1661-1666, 2000.

9. DePAOLA, A. \& HWANG, G.C. - Effect of dilution, incubation-time, and temperature of enrichment on cultural and PCR detection of Vibrio cholerae obtained from oyster Crassostrea virginica. Molec. Cell. Probes, 9: 75-81, 1995.

10. DONOVAN, T.J. \& VAN NETTEN, P. - Culture media for the isolation and enumeration of pathogenic Vibrio species in foods and environmental samples. Int. J. Food Microbiol., 26: 77-91, 1995.

11. ELLIOT, E.L.; KAYSNER, C.A.; JACKSON, L. \& TAMPLIN, M.L. - Vibrio cholerae V. parahaemolyticus, V. vulnificus, and other Vibrio spp. In Bacteriological Analytical Manual. 8. ed. Revision A, 2001. Chapter 9. Available: URL:http:// www.cfsan.fda.gov/ ebam/bam-9.html. Accessed in: 20/07/2003.

12. GENTHNER, F.J.; VOLETY, A.K.; OLIVER, L.M. \& FISHER, W.S. - Factors influencing in vitro killing of bacteria by hemocytes of the eastern oyster (Crassostrea virginica). Appl. environ. Microbiol., 65: 3015-3020, 1999.

13. HARA-KUDO, Y.; NISHINA, T.; NAKAGAWA, H. et al. - Improved method for detection of Vibrio parahaemolyticus in seafood. Appl. environ. Microbiol., 67: 5819-5823, 2001.

14. HARRIS-YOUNG, L.; TAMPLIN, M.L.; FISHER, W.S. \& MASON, J.W. - Effects of physicochemical factors and bacterial colony morphotype on association of Vibrio vulnificus with hemocytes of Crassostrea virginica. Appl. environ. Microbiol., 59: 1012-1017, 1993

15. HOFER, E. \& ERNANDEZ, D. - Incidência de Vibrio cholerae não O1 em afluentes de estações de tratamento de esgotos da cidade do Rio de Janeiro, RJ. Rev. Microbiol. (S. Paulo), 21: 31-40, 1990. 
SOUSA, O.V.; VIEIRA, R.H.S.F.; MENEZES, F.G.R.; REIS, C.M.F. \& HOFER, E. - Detection of Vibrio parahaemolyticus and Vibrio cholerae in oyster, Crassostrea rhizophorae collected from a natural nursery in the Cocó river estuary, Fortaleza, Ceará, Brazil. Rev. Inst. Med. trop. S. Paulo, 46(2):59-62, 2004.

16. HUBERT, F.; VAN DER KNAAP, W.; NOEL, T. \& ROCH, P. - Cytotoxic and antibacterial properties of Mytilus galloprovincialis, Ostrea edulis and Crassostrea gigas (bivalve molluscs) hemolymph. Aquat. Living Resources, 9: 115-124, 1996.

17. LEE, R.J. \& YOUNGER, A.D. - Developing microbiological risk assessment for shellfish purification. Int. Biodeter. Biodegrad., 50: 177-183, 2002.

18. LEITÃO, M.F.F. - Microbiologia de alimentos. In: ROITMAN, I.; TRAVASSOS, L.R. \& AZEVEDO, J.L., ed. Tratado de Microbiologia. São Paulo, Manole, 1988. v.1, p. 3-81.

19. MORRIS Jr., J.G. \& BLACK, R.E. - Cholera and other vibrioses in the United States. New Engl. J. Med., 312: 343-349, 1985.

20. NAMDARI, H.; KLAIPS, C.R. \& HUGHES, J.L. - A cytotoxin-producing strain of Vibrio cholerae non-O1, non-O139 as a cause of cholera and bacteremia after consumption of raw clams. J. clin. Microbiol., 38: 3518-3819, 2000.
21. O'HARA, C.M.; BRENNER, F.W. \& MILLER, J.M. - Classification, identification, and clinical significance of Proteus, Providencia, and Morganella. Clin. Microbiol. Rev. 13: $534-546,2000$

22. RIPPEY, S.R. - Infectious diseases associated with molluscan shellfish consumption. Clin. Microbiol. Rev., 7: 419-425, 1994.

23. RODRIGUES, D.P. \& HOFER, E. - Vibrio species from the water-oyster ecosystem of Sepetiba bay in Rio de Janeiro state, Brazil. Rev. Microbiol. (S. Paulo), 17: 332 338, 1986.

24. TAMPLIN, M.L. - Coastal vibrios: identifying relationships between environmental condition and human disease. Human ecol. Risk Assess., 7: 1437-1445, 2001.

25. XU, H.S.; ROBERTS, N.; SINGLETON, F.L. et al. - Survival and viability of nonculturable Escherichia-coli and Vibrio-cholerae in the estuarine and marineenvironment. Microb. Ecol., 8: 313-323, 1982.

Received: 29 December 2003

Accepted: 9 February 2004 